\section{Virulence Phenotypes on Chili Pepper for Phytophthora capsici Isolates from Michoacán, Mexico}

\author{
Alfredo Reyes-Tena \\ Instituto de Investigaciones Agropecuarias y Forestales, Universidad \\ Michoacana de San Nicolás de Hidalgo, Km. 9.5 Carretera Morelia- \\ Zinapécuaro, 58880 Tarímbaro, Michoacán, Mexico
}

\section{Arturo Castro-Rocha}

Tecnologico de Monterrey, Av. Eugenio Garza Sada 2501 Sur, Monterrey, 64849 Nuevo León, Mexico

\section{Gerardo Rodríguez-Alvarado}

Instituto de Investigaciones Agropecuarias y Forestales, Universidad Michoacana de San Nicolás de Hidalgo, Km. 9.5 Carretera MoreliaZinapécuaro, 58880 Tarímbaro, Michoacán, Mexico

\section{Gerardo Vázquez-Marrufo}

Centro Multidisciplinario de Estudios en Biotecnología, Universidad Michoacana de San Nicolás de Hidalgo, Km. 9.5 Carretera MoreliaZinapécuaro, 58880 Tarímbaro, Michoacán, Mexico

\section{Martha Elena Pedraza-Santos}

Facultad de Agrobiología, Universidad Michoacana de San Nicolás de Hidalgo, Paseo Gral. Lázaro Cárdenas y Berlín s/n, Viveros, 60170 Uruapan, Michoacán, Mexico

\section{Kurt Lamour}

Department of Entomology and Plant Pathology, University of Tennessee, Knoxville, TN, 37996

\section{John Larsen}

Instituto de Investigaciones en Ecosistemas y Sustentabilidad, Antigua Carretera a Pátzcuaro 8701, Col. Ex Hacienda de San José de la Huerta, 58190 Morelia, Michoacán, Mexico

\section{Sylvia Patricia Fernández-Pavía ${ }^{1}$}

Instituto de Investigaciones Agropecuarias y Forestales, Universidad Michoacana de San Nicolás de Hidalgo, Km. 9.5 Carretera MoreliaZinapécuaro, 58880 Tarímbaro, Michoacán, Mexico

Additional index words. Capsicum annuum, differential hosts, Oomycetes, pepper wilt, root rot

\footnotetext{
Abstract. Phytophthora blight of vegetables caused by Phytophthora capsici causes significant economic losses in production of Solanaceae and Cucurbitaceae crops in Mexico. The development of universal resistant chili pepper cultivars is challenging due to the diverse virulence phenotypes produced by $P$. capsici. The objective of the study was to characterize the diversity of phenotypic interactions for $P$. capsici isolates recovered from production fields in Michoacán, Mexico, to facilitate the development of resistant cultivars. Virulence phenotypes were characterized for 12 isolates of $P$. capsici using 26 Capsicum annuum New Mexico Recombinant Inbred Lines (NMRILs) in greenhouse conditions. Criollo de Morelos CM-334 and California Wonder were used as resistant and susceptible controls, respectively. Seedlings at the four to eight true leaf stage were inoculated with 10,000 zoospores per seedling and disease severity was evaluated at 20 days post-inoculation. Two of the $P$. capsici isolates did not infect any pepper host even though the isolate was less than a year old. The 10 virulent isolates were designated in 10 virulence phenotypes. The information generated by this study is of utmost importance for efforts of producing resistant cultivars specific for Michoacán producers.
}

The oomycete Phytophthora capsici is highly destructive to vegetable species in the Solanaceae, Cucurbitaceae, and Fabaceae families (Kamoun et al., 2015). Worldwide, it is the main pathogen limiting chili pepper (Capsicum annuum) production and can infect the roots, crown, stem, and fruits (Barchenger et al., 2018a; García-Rodríguez et al., 2010; Glosier et al., 2008; Lamour and Hausbeck, 2002). In Mexico, P. capsici primarily attacks the roots, and foliar blight is rare in production fields (Macías-Valdez et al., 2010). P. capsici has an asexual phase characterized by the rapid production of deciduous sporangia on infected tissues, which can quickly release swimming zoospores under wet conditions. The sexual phase requires the interaction of two mating types (A1 and A2), and outcrossing can greatly increase the genetic diversity of field populations and may increase the overall evolutionary potential and the ability to adapt to control measures (Lamour et al., 2012). Recently, variable ploidy has been reported in this pathogen and could affect its ability to adapt to different environments (Barchenger et al., 2017).

In Mexico, the presence of $P$. capsici has been reported in multiple vegetable production zones and is considered the main cause of chili pepper root rot (Silva-Rojas et al., 2009). The use of chemical fungicides has been a costly and ineffective strategy to control this pathogen and may be harmful to the environment (García-Rodríguez et al., 2010). Among the alternatives to control $P$. capsici, the development of resistant cultivars could be the best method to reduce the losses associated with this plant pathogen (Gómez-Rodríguez et al., 2017). However, the development of resistant cultivars and varieties to $P$. capsici has been difficult due to the presence of diverse virulence phenotypes of this pathogen (Barchenger et al., 2018b; Jiang et al., 2015; Oelke et al., 2003; Sy et al., 2008).

Virulence phenotype characterization requires a set of host plants carrying one or more resistant genes with recombinant inbred lines (RILs) often used for race-typing (Oelke et al., 2003). Regarding the Capsicum annuum-P. capsici pathosystem, Sy et al. (2008) reported the development of a series of differential host lines specifically for the characterization in $P$. capsici known as the New Mexico Recombinant Inbred Lines (NMRILs). The NMRILs were developed by crossing the landrace Criollo de Morelos CM-334 (considered a universally resistant host) with the highly susceptible variety Early Jalapeño. A subset of the resulting progeny was then selfed until the $\mathrm{F}_{7}$ generation and 26 lines were further selected as useful to differentiate $P$. capsici isolates based on resistance/susceptibility reactions.

The NMRILs have been used to characterize $P$. capsici physiological races from isolates of different regions and are a valuable tool to characterize $P$. capsici isolates at a global scale. Recently, the term "race" has been replaced by the term "virulence 
phenotype" to characterize the interaction of $P$. capsici isolates on RILs carrying various host resistance genes (Barchenger et al., 2018b). By using the NMRILs, 12 P. capsici root rot virulence phenotypes were characterized from isolates recovered from New Mexico, 11 from isolates recovered from Brazil, and 24 from isolates recovered from Taiwan (Barchenger et al., 2018b; da Costa Ribeiro and Bosland, 2012; Jiang et al., 2015). The NMRILs have also been used to characterize foliar blight virulence phenotypes (MonroyBarbosa and Bosland, 2010; Monroy-Barbosa and Bosland, 2011).

Characterizing the virulence phenotypes present in production zones is useful in the development of resistant lines (Glosier et al., 2008). A promising approach is the introgression of specific resistance genes that could lead to multiresistant cultivars (da Costa Ribeiro and Bosland, 2012). In Mexico, there are no reports on the presence or characterization of virulence phenotypes of isolates of $P$. capsici recovered from production zones. Due to the high genetic diversity of this pathogen in Mexico (Castro-Rocha et al., 2016), it is likely that multiple virulence phenotypes exist in field populations. The objective of this study was to characterize the virulence phenotypes for $P$. capsici isolates recovered from Solanaceae and Cucurbitaceae production fields in Michoacán, Mexico using the NMRILs.

\section{Materials and Methods}

Differential hosts. For the present study, 26 NMRILs were used as differential hosts (Sy et al., 2008). The tested lines were: A, AA, AB, AC, B, C, D, E, F, G, H, I, J, K, L, $\mathrm{M}, \mathrm{N}, \mathrm{O}, \mathrm{P}, \mathrm{Q}, \mathrm{R}, \mathrm{S}, \mathrm{T}, \mathrm{V}, \mathrm{X}$, and $\mathrm{Z}$. The starting seeds of the NMRILs were provided by Dr. Paul Bosland of New Mexico State University. The NMRILs were grown in greenhouse conditions to obtain enough seed for the complete experiment. Criollo de Morelos CM-334 was used as resistant control and California Wonder (CW) as susceptible control (Seed brand "Los Molinos," Morelos, Mexico). Seedlings were grown in germination trays divided in six sections of $100 \mathrm{~cm}^{3}$ using Sunshine Mix 3 (90\% Canadian peatmoss, $10 \%$ plant starter mix) as substrate. Thirty days after germination, each plant was

\footnotetext{
Received for publication 22 Feb. 2019. Accepted for publication 7 June 2019.

The first author thanks the National Council for Science and Technology of Mexico (CONACYT) for his doctoral studies scholarship. The authors thank Paul W. Bosland of New Mexico State University for donating the NMRIL seeds set; José de Jesús Luna Ruiz of the Universidad Autónoma de Aguascalientes for donating the Criollo de Morelos CM334 seeds; and Daniela Pineda-Vaca and Erica Goss for skilled technical assistance.

This paper is a portion of a thesis presented by Alfredo Reyes-Tena, for the fulfillment of a degree requirement.

${ }^{1}$ Corresponding author. E-mail: fpavia@umich. $\mathrm{mx}$.
}

fertilized once per week with $20 \mathrm{~mL}$ of Miraclegro universal fertilizer $(24 \mathrm{~N}-8 \mathrm{P}-16 \mathrm{~K})$.

Collection of isolates of Phytophthora capsici and determination of mating type. Twelve $P$. capsici isolates were recovered from Capsicum annuum, Solanum lycopersicum, and Cucurbita pepo plants with root rot in eight production fields of the municipalities of Copándaro, Morelia, Queréndaro, Tacámbaro, and Tarímbaro in Michoacán state (Figs. 1 and 2, Table 1). The following isolates were collected from the same field: CPV-259 and CPV-260 from a field located in Copándaro; CPV-270, CPV-271, and CPV-272 from a field located in Tarímbaro; and CPV-277 and CPV-279 from a field located in Queréndaro. Plant tissues were rinsed with running tap water; small diseased tissue fragments were cut $(1.0 \times 0.5 \mathrm{~cm})$, disinfested with $10 \%$ commercial chlorine solution ( $6 \%$ sodium hypochlorite) for $30 \mathrm{~s}$, rinsed with sterile distilled water twice, blotted dry with sterile paper towels, transferred to NARPH-V8 plates [Delvocid Instant (0.02 $\left.\mathrm{g} \cdot \mathrm{L}^{-1}\right) ;(50 \%$ natamycin, $50 \%$ lactose $\left.)\right]$, ampicillin $\left(0.27 \mathrm{~g} \cdot \mathrm{L}^{-1}\right)$, rifampicin $\left(0.01 \mathrm{~g} \cdot \mathrm{L}^{-1}\right)$, pentachloronitrobenzene $\left(0.10 \mathrm{~g} \cdot \mathrm{L}^{-1}\right)$, and hymexazol $\left(0.075 \mathrm{~g} \cdot \mathrm{L}^{-1}\right)$ and incubated at $25^{\circ} \mathrm{C}$ in the dark.

Mating type was determined by following the protocol described by Yin et al. (2012). All recovered isolates were placed in pairs with known A1 and A2 isolates on V8-agar medium in petri dishes at a distance of $3 \mathrm{~cm}$ from each other and incubated at $25{ }^{\circ} \mathrm{C}$ for five days. After the incubation period, isolates were examined for oospore formation.

Molecular characterization of Phytophthora capsici isolates. The isolates CPV-1, CPV33 and $\mathrm{CH} 11$ were previously reported as $P$. capsici by SNP sequencing (Castro-Rocha et al., 2016). The isolates CPV-267, CPV270, and CPV-277 were reported as $P$. capsici by whole genome sequencing (Reyes-Tena et al., 2019). Genomic DNA was extracted from the isolates CPV-259, CPV-260, CPV-271, CPV-272, CPV-273, and CPV-279, following the method described by Saghai-Maroof et al. (1984). Whole genomes were sequenced and assembled following the method reported by Reyes-Tena et al. (2019). A blast analysis was conducted to infer cytochrome oxidase
1 (cox 1$)$ and cytochrome oxidase 2 (cox2) genes and determinate the identity of the isolates.

Differential host's inoculation. Host inoculation was performed as described by Bosland and Lindsay (1991) with modifications. Each isolate was transferred to V8 agar petri dishes $(150 \times 15 \mathrm{~mm})$. Once the growth media was completely colonized by the isolates, the agar was cut into $1 \mathrm{~cm}^{2}$ fragments and transferred to new petri dishes afterward sterilized distilled water was added to each petri dish until the mycelium fragments were completely covered up to the margin. The cultured isolates were kept under white light at $25^{\circ} \mathrm{C}$ and water was changed every $24 \mathrm{~h}$ over 3 consecutive days. Once the isolates produced sporangia, they were subjected to a temperature shock treatment of $30 \mathrm{~min}$ at $4{ }^{\circ} \mathrm{C}$ and $30 \mathrm{~min}$ at $24{ }^{\circ} \mathrm{C}$ to induce zoospore release. A sample of the zoospores containing liquid was used to quantify the zoospores in a Neubauer chamber using a drop of lactophenol blue to stain and immobilize them. A suspension containing $1 \times 10^{4}$ zoospores $/ \mathrm{mL}$ was prepared for each isolate used in the experiment. One milliliter of the suspension was used as the inoculum for the resistance/ susceptibility tests. The experimental unit consisted of a single plant inoculated with zoospores of a single isolate of the pathogen. Each tray had six repetitions of the same experimental unit. After the inoculation with $P$. capsici, the trays were placed in closed trays that had $4 \mathrm{~cm}$ of water and were randomly distributed in greenhouse benches to diminish the effect of environmental factors on the development of disease symptoms. The complete experiment had 26 NMRILs, two controls (resistant and susceptible), 12 isolates, controls without inoculum, and 6 replications for a total of $28 \times 13 \times 6=$ 2184 experimental units. Host plants were tested at the four to eight true leaf stage by inoculating them with 10,000 zoospores in the substrate next to the stem, with the aid of a dosing syringe (Ape; $50 \mathrm{~mL}$ ). To allow a successful plant-pathogen interaction, the substrate of the host plants was saturated with water for $24 \mathrm{~h}$ after the inoculation. Noninoculated control plants were subjected to the same conditions but were not inoculated with zoospores. The pathogen was reisolated from plants with symptoms.

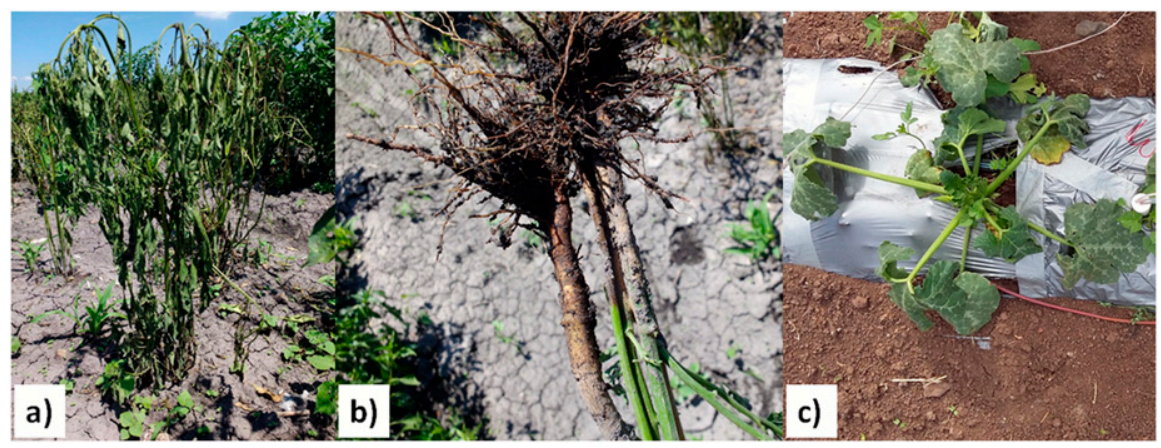

Fig. 1. Plants with symptoms caused by Phytophthora capsici in the field: (A) wilted pepper plants in a field in Queréndaro, (B) pepper plants with root rot and stem necrosis in Queréndaro, and (C) wilted zucchini plant in Morelia. 


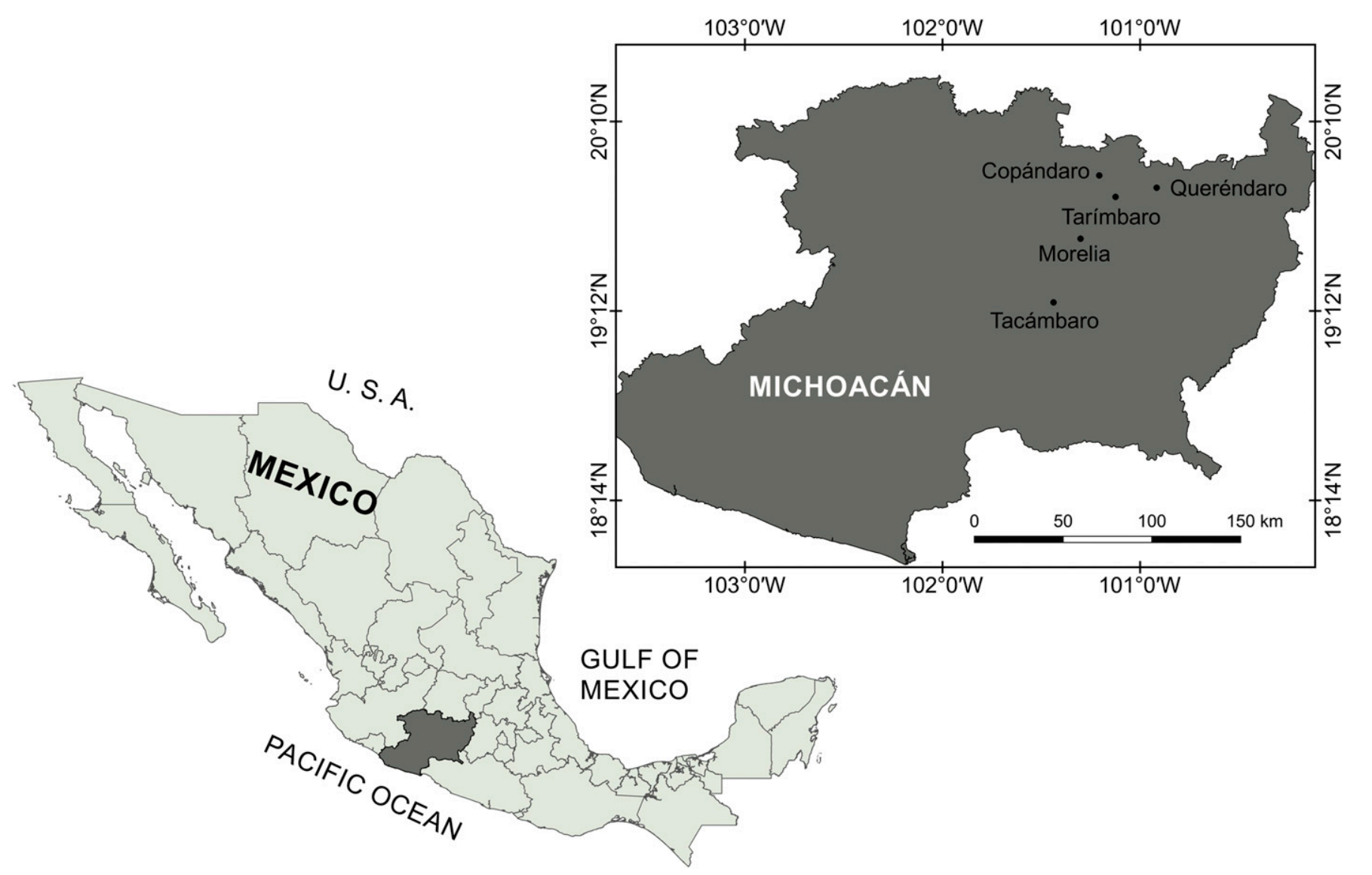

Fig. 2. Map of the sites where the Phytophthora capsici isolates were collected.

Table 1. Municipality, host and collection date of isolates of Phytophthora capsici from Michoacán.

\begin{tabular}{lllc}
\hline Isolate & Municipality & \multicolumn{1}{c}{ Host } & Date of collection \\
\hline CPV-1 & Tacámbaro & Capsicum annuum & 2002 \\
CPV-33 & Tacámbaro & Solanum lycopersicum & 2002 \\
CH11 & Tarímbaro & Capsicum annuum & 2011 \\
CPV-259 & Copándaro & Capsicum annuum & 2016 \\
CPV-260 & Copándaro & Capsicum annuum & 2016 \\
CPV-267 & Morelia & Cucurbita pepo & 2016 \\
CPV-270 & Tarímbaro & Capsicum annuum & 2016 \\
CPV-271 & Tarímbaro & Capsicum annuum & 2016 \\
CPV-272 & Tarímbaro & Capsicum annuum & 2016 \\
CPV-273 & Tarímbaro & Solanum lycopersicum & 2016 \\
CPV-277 & Queréndaro & Capsicum annuum & 2017 \\
CPV-279 & Queréndaro & Capsicum annuum & 2017 \\
\hline
\end{tabular}

${ }^{\mathrm{z}}$ Municipality of Michoacán, Mexico.

Disease scoring. The severity of the disease was scored based on the following scale: $0=$ no symptoms/healthy plant; $1=$ yellow leaves without stem necrosis; $2=$ minor stem necrosis; 3 = moderate stem necrosis and early signs of wilting; 4 = plant with severe stem necrosis and wilting; $5=$ dead plant (Glosier et al., 2008).

The evaluation was performed at $20 \mathrm{~d}$ postinoculation (dpi). At this time, susceptible control plants exhibited severe stem necrosis and wilting. The average disease severity for each host*isolate interaction was calculated.

Virulence phenotype determination and data analysis. The $P$. capsici virulence phenotypes were determined based on the unique resistant/susceptible interaction pattern on the differential lines. A unique resistance/ susceptibility pattern on the differential hosts set was considered a unique virulence phenotype. The following criteria were used to determine if the plant hosts were resistant or susceptible: hosts with an average disease severity of 0 were considered resistant; hosts with an average diseases severity greater than 0 were considered susceptible. In addition, the data obtained from the severity scale on differential hosts were compared with the results obtained from the resistant and susceptible controls by using a chi-square test of homogeneity at a confidence level of $99 \%$. Differential hosts lines that differed statistically from the resistant controls were considered susceptible (Ho). Differential hosts lines that did not differ statistically from the susceptible controls were considered susceptible (Ha).

\section{Results and Discussion}

The cox 1 and cox 2 genes from the assembled genomes had at least $98 \%$ similarity to isolates of $P$. capsici in GenBank, and the isolates CPV-259, CPV-260, CPV-271, CPV-272, CPV-273, and CPV-279 were identified as $P$. capsici. Ten of the isolates were able to cause infection on at least one of the differential lines and each of these pathogenic isolates produced a unique virulence phenotype using the NMRILs as differential hosts (Table 2). Ten virulence phenotypes differ from all previously reported and the prefix "MX" has been appended to their designations to indicate their unique geographical occurrence. Not all NMRILs are needed for the identification of new virulence phenotypes, and the 10 new ones reported here are determined based on their differential reactions with six NMRILs (G, I, M, N, $\mathrm{O}$, and $\mathrm{AC}$; Table 3 ). In previous reports, $7-$ 10 NMRILs were used to determine the virulence phenotypes of $P$. capsici isolates (Barchenger et al., 2018b; da Costa Ribeiro and Bosland, 2012; Jiang et al., 2015; Sy et al., 2008). Ideally, molecular markers could be used to determine virulence phenotypes and the use of a standardized set of differentials (e.g., NMRILs) is crucial to gain a reasonable estimate to support marker development (Barchenger et al., 2018b). Currently, in planta greenhouse experiments with differential hosts are the most effective 


\begin{tabular}{|c|c|c|c|c|c|c|c|c|c|c|}
\hline \multicolumn{11}{|c|}{ Isolate $^{z}$} \\
\hline Host & $\begin{array}{c}\text { CPV- } \\
279\end{array}$ & $\begin{array}{c}\text { CPV- } \\
277\end{array}$ & $\mathrm{CH} 1 \mathrm{l}$ & $\begin{array}{c}\text { CPV- } \\
260\end{array}$ & CPV-1 & $\begin{array}{c}\text { CPV- } \\
272\end{array}$ & $\begin{array}{c}\text { CPV- } \\
271\end{array}$ & $\begin{array}{c}\text { CPV- } \\
259\end{array}$ & CPV-33 & $\begin{array}{c}\text { CPV- } \\
267\end{array}$ \\
\hline $\mathrm{CM}-334^{\mathrm{y}}$ & $\mathrm{R}^{\mathrm{v}}$ & $\mathrm{R}$ & $\mathrm{R}$ & $\mathrm{R}$ & $\mathrm{R}$ & $\mathrm{R}$ & $\mathrm{R}$ & $\mathrm{R}$ & $\mathrm{R}$ & $\mathrm{R}$ \\
\hline NMRIL-T ${ }^{\mathrm{x}}$ & $\mathrm{R}$ & $\mathrm{R}$ & $\mathrm{R}$ & $\mathrm{R}$ & $\mathrm{R}$ & $\mathrm{R}$ & $\mathrm{R}$ & $\mathrm{R}$ & $\mathrm{R}$ & $\mathrm{R}$ \\
\hline NMRIL-Z & $\mathrm{R}$ & $\mathrm{R}$ & $\mathrm{R}$ & $\mathrm{R}$ & $\mathrm{R}$ & $\mathrm{R}$ & $\mathrm{R}$ & $\mathrm{R}$ & $\mathrm{R}$ & $\mathrm{R}$ \\
\hline NMRIL-P & $\mathrm{S}^{\mathrm{v}}$ & $\mathrm{R}$ & $\mathrm{R}$ & $\mathrm{R}$ & $\mathrm{R}$ & $\mathrm{R}$ & $\mathrm{R}$ & $\mathrm{R}$ & $\mathrm{R}$ & $\mathrm{R}$ \\
\hline NMRIL-F & $\mathrm{R}$ & $\mathrm{R}$ & $\mathrm{R}$ & $\mathrm{S}$ & $\mathrm{R}$ & $\mathrm{R}$ & $\mathrm{R}$ & $\mathrm{R}$ & $\mathrm{R}$ & $\mathrm{R}$ \\
\hline NMRIL-X & $\mathrm{R}$ & $\mathrm{R}$ & S & $\mathrm{R}$ & $\mathrm{R}$ & $\mathrm{R}$ & $\mathrm{R}$ & $\mathrm{R}$ & $\mathrm{R}$ & $\mathrm{R}$ \\
\hline NMRIL-A & $\mathrm{S}$ & $\mathrm{S}$ & $\mathrm{R}$ & $\mathrm{R}$ & $\mathrm{R}$ & $\mathrm{R}$ & $\mathrm{R}$ & $\mathrm{R}$ & $\mathrm{R}$ & $\mathrm{R}$ \\
\hline NMRIL-C & $\mathrm{S}$ & $\mathrm{S}$ & $\mathrm{R}$ & $\mathrm{R}$ & $\mathrm{R}$ & $\mathrm{R}$ & $\mathrm{R}$ & $\mathrm{R}$ & $\mathrm{R}$ & $\mathrm{R}$ \\
\hline NMRIL-D & $\mathrm{S}$ & $\mathrm{S}$ & $\mathrm{R}$ & $\mathrm{R}$ & $\mathrm{R}$ & $\mathrm{R}$ & $\mathrm{R}$ & $\mathrm{R}$ & $\mathrm{R}$ & $\mathrm{R}$ \\
\hline NMRIL-E & $\mathrm{S}$ & $\mathrm{S}$ & $\mathrm{R}$ & $\mathrm{R}$ & $\mathrm{R}$ & $\mathrm{R}$ & $\mathrm{R}$ & $\mathrm{R}$ & $\mathrm{R}$ & $\mathrm{R}$ \\
\hline NMRIL-J & $\mathrm{R}$ & $\mathrm{S}$ & $\mathrm{R}$ & $\mathrm{S}$ & $\mathrm{R}$ & $\mathrm{R}$ & $\mathrm{R}$ & $\mathrm{R}$ & $\mathrm{R}$ & $\mathrm{R}$ \\
\hline NMRIL-K & $\mathrm{S}$ & $\mathrm{S}$ & $\mathrm{R}$ & $\mathrm{R}$ & $\mathrm{S}$ & $\mathrm{R}$ & $\mathrm{R}$ & $\mathrm{R}$ & $\mathrm{R}$ & $\mathrm{R}$ \\
\hline NMRIL-O & $\mathrm{R}$ & $\mathrm{R}$ & $\mathrm{R}$ & $\mathrm{S}$ & $\mathrm{R}$ & $\mathrm{R}$ & $\mathrm{S}$ & $\mathrm{R}$ & $\mathrm{R}$ & $\mathrm{R}$ \\
\hline NMRIL-Q & $\mathrm{S}$ & $\mathrm{R}$ & $\mathrm{R}$ & $\mathrm{R}$ & $\mathrm{R}$ & $\mathrm{S}$ & $\mathrm{R}$ & $\mathrm{R}$ & $\mathrm{R}$ & $\mathrm{R}$ \\
\hline NMRIL-R & $\mathrm{S}$ & $\mathrm{R}$ & $\mathrm{R}$ & $\mathrm{S}$ & $\mathrm{R}$ & $\mathrm{R}$ & $\mathrm{R}$ & $\mathrm{R}$ & $\mathrm{R}$ & $\mathrm{R}$ \\
\hline NMRIL-S & $\mathrm{R}$ & $\mathrm{S}$ & $\mathrm{R}$ & $\mathrm{R}$ & $\mathrm{R}$ & $\mathrm{R}$ & $\mathrm{R}$ & $\mathrm{S}$ & $\mathrm{R}$ & $\mathrm{R}$ \\
\hline NMRIL-AA & $\mathrm{S}$ & $\mathrm{S}$ & $\mathrm{R}$ & $\mathrm{R}$ & $\mathrm{R}$ & $\mathrm{R}$ & $\mathrm{R}$ & $\mathrm{R}$ & $\mathrm{R}$ & $\mathrm{R}$ \\
\hline NMRIL-B & S & $\mathrm{R}$ & S & $\mathrm{R}$ & $\mathrm{R}$ & $\mathrm{R}$ & S & $\mathrm{R}$ & $\mathrm{R}$ & $\mathrm{R}$ \\
\hline NMRIL-L & $\mathrm{S}$ & $\mathrm{S}$ & $\mathrm{S}$ & $\mathrm{R}$ & $\mathrm{R}$ & $\mathrm{R}$ & $\mathrm{R}$ & $\mathrm{R}$ & $\mathrm{R}$ & $\mathrm{R}$ \\
\hline NMRIL-M & $\mathrm{S}$ & $\mathrm{R}$ & $\mathrm{R}$ & $\mathrm{R}$ & $\mathrm{R}$ & $\mathrm{S}$ & $\mathrm{S}$ & $\mathrm{R}$ & $\mathrm{R}$ & $\mathrm{R}$ \\
\hline NMRIL-V & $\mathrm{S}$ & $\mathrm{S}$ & $\mathrm{R}$ & $\mathrm{R}$ & $\mathrm{R}$ & $\mathrm{R}$ & $\mathrm{R}$ & $\mathrm{S}$ & $\mathrm{S}$ & $\mathrm{R}$ \\
\hline NMRIL-AB & $\mathrm{S}$ & $\mathrm{S}$ & $\mathrm{R}$ & $\mathrm{R}$ & $\mathrm{S}$ & $\mathrm{R}$ & $\mathrm{R}$ & $\mathrm{R}$ & $\mathrm{R}$ & $\mathrm{R}$ \\
\hline NMRIL-G & $\mathrm{S}$ & $\mathrm{S}$ & $\mathrm{R}$ & $\mathrm{R}$ & $\mathrm{S}$ & $\mathrm{R}$ & $\mathrm{R}$ & $\mathrm{R}$ & $\mathrm{R}$ & $\mathrm{S}$ \\
\hline NMRIL-H & $\mathrm{R}$ & $\mathrm{R}$ & $\mathrm{S}$ & $\mathrm{R}$ & $\mathrm{S}$ & $\mathrm{S}$ & $\mathrm{R}$ & $\mathrm{S}$ & $\mathrm{R}$ & $\mathrm{R}$ \\
\hline NMRIL-AC & $\mathrm{S}$ & $\mathrm{S}$ & $\mathrm{R}$ & $\mathrm{S}$ & $\mathrm{S}$ & $\mathrm{R}$ & $\mathrm{R}$ & $\mathrm{R}$ & $\mathrm{R}$ & $\mathrm{R}$ \\
\hline NMRIL-I & $\mathrm{S}$ & $\mathrm{S}$ & $\mathrm{S}$ & S & $\mathrm{R}$ & $\mathrm{R}$ & $\mathrm{R}$ & $\mathrm{R}$ & $\mathrm{R}$ & $\mathrm{S}$ \\
\hline NMRIL-N & $\mathrm{S}$ & $\mathrm{S}$ & $\mathrm{S}$ & $\mathrm{R}$ & $\mathrm{R}$ & $\mathrm{S}$ & $\mathrm{S}$ & $\mathrm{R}$ & $\mathrm{S}$ & $\mathrm{R}$ \\
\hline $\mathrm{CW}^{\mathrm{w}}$ & $\mathrm{S}$ & $\mathrm{S}$ & $\mathrm{S}$ & $\mathrm{S}$ & $\mathrm{S}$ & $\mathrm{S}$ & $\mathrm{S}$ & $\mathrm{S}$ & $\mathrm{S}$ & $\mathrm{S}$ \\
\hline
\end{tabular}

Chi-square test of homogeneity showed significant differences between all the infected hosts and the resistant controls

${ }^{\mathrm{Z}}$ Isolates from the Plant Pathology Laboratory culture collection (Universidad Michoacana de San Nicolás de Hidalgo, Morelia, Mexico), ordered from most virulent to least virulent isolate.

${ }^{\mathrm{y}}$ Resistant control: Criollo de Morelos CM-334.

${ }^{\mathrm{x}}$ New Mexico Recombinant Inbred Lines from most resistant to least resistant.

wSusceptible control: 'California Wonder'.

${ }^{\mathrm{v}} \mathrm{R}=$ resistant host; $\mathrm{S}=$ susceptible host.

Table 3. Virulence phenotype designation based on virulence phenotype of 10 isolates of Phytophthora capsici on New Mexico Recombinant Inbred Lines differential hosts.

\begin{tabular}{|c|c|c|c|c|c|c|c|c|c|c|}
\hline Isolate & CPV-279 & CPV-277 & CH11 & CPV-260 & $\mathrm{CPV}-1$ & CPV-272 & CPV-271 & CPV-259 & CPV-33 & CPV-267 \\
\hline Race & $\overline{\mathrm{MX}-1^{\mathrm{z}}}$ & $\overline{M X-2}$ & $\overline{\mathrm{MX}-3}$ & $\overline{M X-4}$ & $\overline{M X-5}$ & $\overline{M X-6}$ & $\overline{M X-7}$ & $\overline{M X-8}$ & $\overline{\text { MX-9 }}$ & $\overline{M X-10}$ \\
\hline$\overline{\text { NMRIL }}$ & \multicolumn{10}{|c|}{ Host response } \\
\hline G & S & S & $\mathrm{R}$ & $\mathrm{R}$ & $\mathrm{R}$ & $\mathrm{R}$ & $\mathrm{R}$ & $\mathrm{S}$ & $\mathrm{R}$ & $\mathrm{S}$ \\
\hline I & $\mathrm{S}$ & $\mathrm{S}$ & $\mathrm{S}$ & $\mathrm{S}$ & $\mathrm{R}$ & $\mathrm{R}$ & $\mathrm{R}$ & $\mathrm{R}$ & $\mathrm{R}$ & $\mathrm{S}$ \\
\hline M & $\mathrm{S}$ & $\mathrm{R}$ & $\mathrm{R}$ & $\mathrm{R}$ & $\mathrm{R}$ & $\mathrm{S}$ & $\mathrm{S}$ & $\mathrm{R}$ & $\mathrm{R}$ & $\mathrm{R}$ \\
\hline $\mathrm{N}$ & $\mathrm{S}$ & $\mathrm{S}$ & $\mathrm{S}$ & $\mathrm{R}$ & $\mathrm{R}$ & $\mathrm{S}$ & $\mathrm{S}$ & $\mathrm{R}$ & $\mathrm{S}$ & $\mathrm{R}$ \\
\hline
\end{tabular}

${ }^{\mathrm{z}}$ Virulence phenotype designation for isolates of Phytophthora capsici from Mexico.

${ }^{\mathrm{y}}$ New Mexico Recombinant Inbred Lines arranged in alphabetic order.

${ }^{\mathrm{x}} \mathrm{R}=$ resistant host; $\mathrm{S}=$ susceptible host.

method due to the limited information concerning genes directly associated with each virulence phenotype.

NMRIL-N was the most susceptible differential host with 6 of the 10 isolates able to infect. Lines $\mathrm{T}$ and $\mathrm{Z}$ were resistant to all isolates. These results differ from Jiang et al. (2015), where line $\mathrm{S}$ was the most susceptible while lines $\mathrm{X}$ and $\mathrm{AE}$ were resistant to infection by isolates from New Mexico. Barchenger et al. (2018b) reported lines A, S, and R as the most susceptible in their experiments and lines $\mathrm{P}$ and $\mathrm{O}$ as the most resistant against isolates from Taiwan. NMRILs resistant to many $P$. capsici isolates could be used as sources of resistance genes for local or regional programs (Barchenger et al., 2018a).
The disease symptoms produced by the virulent isolates ranged in severity (Fig. 3). CPV-279 was the most virulent isolate causing disease symptoms in 18 NMRILs. CPV277 was the second most virulent isolate causing symptoms in 15 of the differential hosts. These isolates were recovered from the same cultivation field and had different mating types (Table 3). Isolates CPV-259 


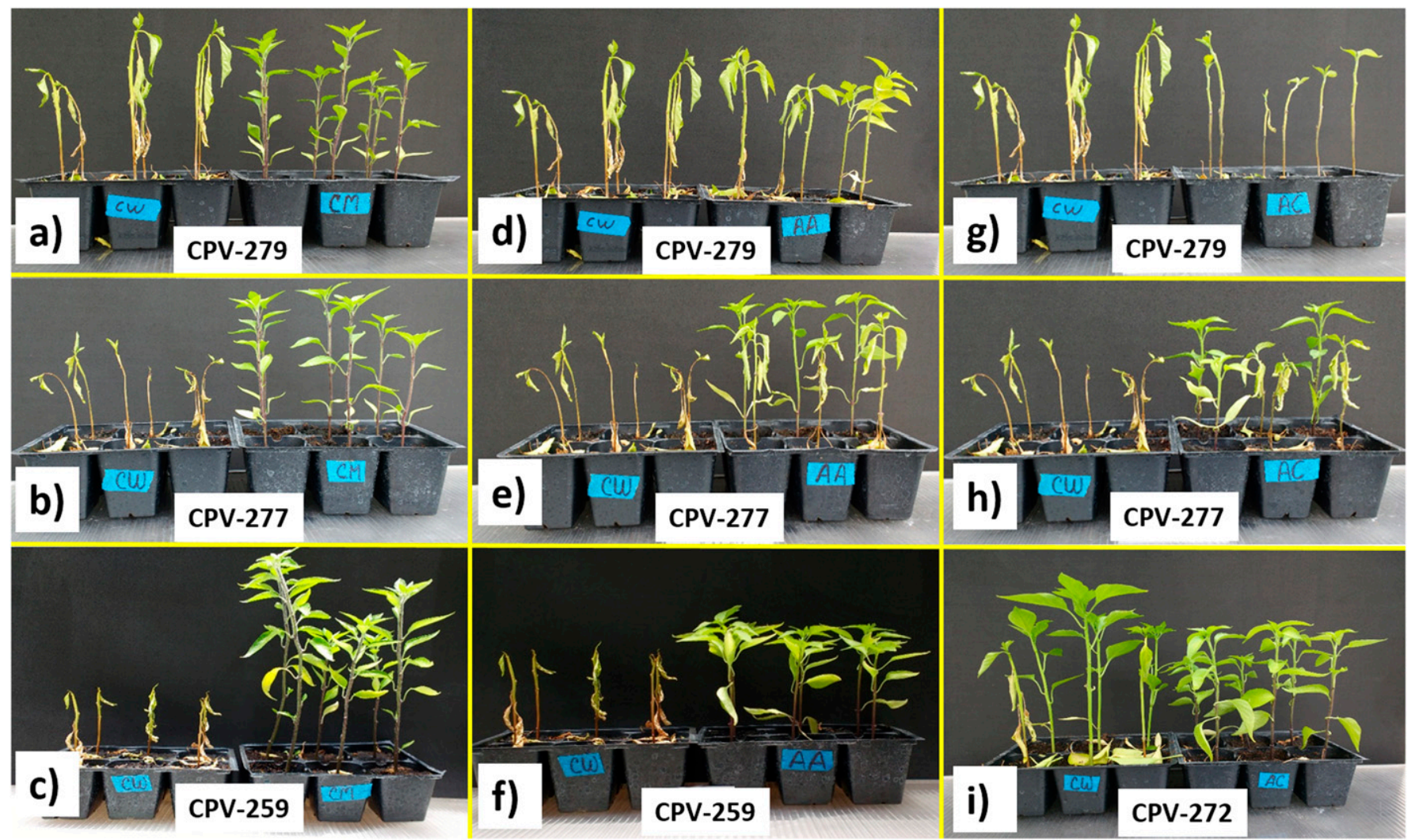

Fig. 3. Disease symptoms exhibited in New Mexico Recombinant Inbred Lines (NMRIL) inoculated with Phytophthora capsici. Controls: (A) = CPV-279: CW (first three pots) and CM334 (second three pots), $(\mathbf{B})=\mathrm{CPV}-277$ : CW (first three pots) and CM334 (second three pots), $(\mathbf{C})=\mathrm{CPV}-259$ : CW (first three pots) and CM334 (second three pots). Phenotypic response in NMRIL-AA: (D) = CPV-279: CW (first three pots) and the susceptible NMRIL-AA (second three pots), $(\mathbf{E})=\mathrm{CPV}-277$ : CW (first three pots) and the susceptible NMRIL-AA, (F) CPV-259: CW (first three pots) and the resistant NMRIL-AA. Phenotypic response in NMRIL-AC: $(\mathbf{G})=\mathrm{CPV}-279$ : CW (first three pots) and the susceptible NMRIL-AC (second three pots), $(\mathbf{H})=\mathrm{CPV}-277$ : CW (first three pots) and the susceptible NMRIL-AC, (I) CPV-272: CW (first three pots) and the resistant NMRIL-AC.

and CPV-260; CPV-270, CPV-271, and CPV272 were recovered from the same field and had different mating types. Given that $P$. capsici is a heterothallic species, this finding suggests that sexual recombination could be occurring and may be important for the generation of new, better adapted, virulence phenotypes (Erwin and Ribeiro, 1996; Polach and Webster, 1972). This represents a challenge for producers because genetic recombination can lead to the emergence of strains capable of breaking the resistance barrier of the hosts (Jiang et al., 2015). The high genetic diversity of $P$. capsici in the center of Mexico (Castro-Rocha et al., 2016) and the high diversity of the Capsicum genus in this country (Aguilar-Meléndez et al., 2009) may drive the evolution of diverse virulence phenotypes in Michoacán. It is necessary to know the virulence phenotype makeup of the $P$. capsici populations in the production fields to be successful in the development of resistant cultivars (Jiang et al., 2015).

The isolates CPV-270 and CPV-273 were not virulent to any host. Nonvirulent $P$. capsici isolates have been reported previously when using the NMRILs as differential hosts (da Costa Ribeiro and Bosland, 2012). The isolate CPV-273 was isolated from Solanum lycopersicum, and it is possible that they were not pathogenic to $C$. annuum due to host specificity (Cohen 2002; Michalska et al., 2016). The remaining isolates were virulent to $\mathrm{CW}$ and at least to one NMRIL. For the isolates that were able to infect at least one NMRIL, CW seedlings had obvious signs of infection thus supporting the use of $\mathrm{CW}$ as a suitable susceptible control (Candole et al., 2012). None of the resistant CM-334 control plants showed any symptoms. The chi-square test of homogeneity showed significant differences between the infected hosts and the resistant controls (Table 2).

This study provides information of phenotypic diversity on pepper for Mexican isolates of $P$. capsici recovered from three hosts. One limitation of this study was the low number of isolates used. Further studies will require characterization of a higher number of isolates from each host, with the goal of obtaining a more robust virulence phenotype structure. These three hosts are cultivated in the same fields in most of the sampled sites, an activity that is harmful to producers because it allows the survival of the virulence phenotypes of $P$. capsici throughout the seasons. A better crop rotation program is required to decrease the inoculum concentration. Crop rotation for 3 years with nonsusceptible hosts is recommended because the oospores can survive and remain virulent in soils (Babadoost and Pavon, 2013; Ristaino and Johnston, 1999).
Overall, our results concur with other studies where NMRILs were successfully used as differential hosts to identify $P$. capsici virulence phenotypes from different parts of the world including the United States, Brazil, and Taiwan (Barchenger et al., 2018b; da Costa Ribeiro and Bosland, 2012; Jiang et al., 2015; Sy et al., 2008). Also, the NMRILs are useful to designate virulence phenotypes in $P$. capsici isolates from noncapsicum hosts. This was previously demonstrated by da Costa Ribeiro and Bosland (2012) and might provide a basis for determining the existence of special forms. One of the main limiting factors for the development of universally resistant cultivars is the lack of a standardized system for $P$. capsici virulence phenotypes determination (Barchenger et al., 2018b). Some studies have used commercial cultivars as differential hosts (Glosier et al., 2008; Oelke et al., 2003) which makes it difficult to compare results. Commercial pepper cultivars are not available worldwide and have the risk of gene segregation (Monroy-Barbosa and Bosland, 2011), therefore the use of the NMRILs could be a viable alternative for a standardized test (Barchenger et al., 2018b).

The use of tolerant and resistant varieties is a low cost and environmentally friendly alternative that is easy to implement by producers (Hausbeck and Lamour, 2004). Creole 
cultivars of "Huacle" and "Serrano" cultivars found in Mexico are resistant to some isolates of $P$. capsici (Gómez-Rodríguez et al., 2017; Palma-Martínez et al., 2017). Preliminary results show that native cultivars of "Pasilla" type chili pepper plants from the municipality of Queréndaro, Michoacán, are tolerant to some $P$. capsici isolates when inoculated with $1 \times 10^{5}$ zoospores (data not shown). Now that $10 \mathrm{P}$. capsici virulence phenotypes have been identified from the same geographic area, the next step would be to test the resistance of this tolerant plant material.

Our research provides important first results about the presence and composition of virulence phenotypes in the populations of $P$. capsici in production fields in Michoacán and is useful to producers of the state. The NMRILs were shown to be a valuable tool to designate virulence phenotype in $P$. capsici isolates of Mexico. The presence of multiple virulence phenotypes and of both mating types in the same production field suggests that outcrossing and sexual recombination may play a role in the emergence of new strains that could overcome host resistance. Knowledge of the virulence phenotypes composition within the populations of these production fields is useful in the decision-making process when developing resistant cultivars and disease management strategies. Further studies about the virulence phenotype structure in more regions from Mexico using the NMRILs, coupled with increased genetic diversity data, will help researchers and producers better understand the epidemiology of the disease in the country.

\section{Literature Cited}

Aguilar-Meléndez, A., P.L. Morrell, M.L. Roose, and K. Seung-Chul. 2009. Genetic diversity and structure in semiwild and domesticated chili (Capsicum annuum; Solanaceae) from Mexico. Amer. J. Bot. 96:1190-1202.

Babadoost, M. and C. Pavon. 2013. Survival of oospores of Phytophthora capsici in soil. Plant Dis. 97:1478-1483.

Barchenger, D.W., K.H. Lamour, S. Zong-Ming, S. Shrestha, S. Kumar, L. Shih-Wen, R. Burlakoti, and P.W. Bosland. 2017. Intra- and intergenomic variation of ploidy and clonality characterize Phytophthora capsici on Capsicum sp. in Taiwan. Mycol. Prog. 16:955-963.

Barchenger, D.W., K.H. Lamour, and P.W. Bosland. 2018a. Challenges and strategies for breeding resistance in Capsicum annuиm to the multifarious pathogen, Phytophthora capsici. Front. Plant Sci. 9:1-16.

Barchenger, D.W., Z.M. Sheu, S. Kumar, W.S. Lin, R.R. Burlakoti, and P.W. Bosland. 2018b. Race characterization of Phytophthora root rot on Capsicum in Taiwan as a basis for anticipatory resistance breeding. Phytopathology 9: $1-16$.

Bosland, P.W. and D.L. Lindsay. 1991. A seedling screening for Phytophthora root rot of pepper, Capsicum annuum. Plant Dis. 75:1048-1050.

Candole, B.L., P.J. Conner, C. McGregor, V. Waters, and P. Ji. 2012. The disease reactions of heirloom bell pepper "California Wonder" to Phytophthora capsici. Agri. Sci. 3:417-424. Castro-Rocha, A., S. Shrestha, B. Lyon, G.L. Grimaldo-Pantoja, J.P. Flores-Marges, J. Valero-Galván, M. Aguirre-Ramírez, P. Osuna-Ávila, N. Gómez-Dorantes, G. ÁvilaQuezada, J.J. Luna-Ruíz, G. Rodríguez-Alvarado, S.P. Fernández-Pavía, and K. Lamour. 2016. An initial assessment of genetic diversity for Phytophthora capsici in northern and central Mexico. Mycol. Prog. 15:15.

Cohen, Y. 2002. Populations of Phytophthora infestans in Israel underwent three major genetic changes during 1983 to 2000 . Phytopathology 92:300-307.

da Costa Ribeiro, C.S. and P.W. Bosland. 2012 Physiological race characterization of Phytophthora capsici isolates from several host plant species in Brazil using New Mexico Recombinant Inbred Lines of Capsicum annuum at two inoculum levels. J. Amer. Soc. Hort. Sci. 137:421-426.

Erwin, D.C. and O.K. Ribeiro. 1996. Phytophthora disease worldwide. American Phytopathology Society Press, St. Paul, MN.

García-Rodríguez, M.R., E. Chiquito-Almanza, P.D. Loeza-Lara, H. Godoy-Hernández, E. Villordo-Pineda, J.L. Pons-Hernández, M.M. González-Chavira, and J.L. Anaya-López. 2010. Producción de chile ancho injertado sobre Criollo de Morelos 334 para el control de Phytophthora capsici. Agrociencia 44:701-709.

Glosier, B.R., E.A. Ogundiwin, G.S. Sidhu, D.R. Sischo, and J.P. Prince. 2008. A differential series of pepper (Capsicum annuum) lines delineates fourteen physiological races of Phytophthora capsici. Euphytica 162:23-30.

Gómez-Rodríguez, O., T. Corona-Torres, and V.H. Aguilar-Rincón. 2017. Differential response of pepper (Capsicum annuum L.) lines to Phytophthora capsici and root-knot nematodes. Crop Prot. 92:148-152.

Hausbeck, M.K. and K. Lamour. 2004. Phytophthora capsici on vegetable crops: Research progress and management challenges. Plant Dis. 88:1292-1303.

Jiang, L., S. Sanogo, and P.W. Bosland. 2015. Using Recombinant Inbred Lines to monitor changes in the race structure of Phytophthora capsici in chile pepper in New Mexico. Plant Health Prog. 16:235-240.

Kamoun, S., O. Furzer, J.D.G. Jones, H.S. Judelson, G.S. Ali, R.J.D. Dalio, S.G. Roy, L. Schena, A Zambounis, F. Penabieres, D. Cahill, M. Ruocco, A. Figueiredo, C. Xiao-Ren, J. Hulvey, R. Stam, K. Lamour, M. Gijzen, B.M. Tyler, N.J. Grünwald, M.S. Mukhtar, D.F.A. Tomé, M. Thör, G. Van den Ackerveken, J. McDowell, F. Daayf, W.E. Fry, H. Lindqvist-Kreuze, H.J.G. Meijer, B. Petre, J. Ristaino, K. Yoshida, P.R.J. Birch, and F. Govers. 2015. The top 10 oomycete pathogens in molecular plant pathology. Mol. Plant Pathol. 16:413-434.

Lamour, K.H. and M.K. Hausbeck. 2002. The spatiotemporal genetic structure of Phytophthora capsici in Michigan and implications for disease management. Phytopathology 92:681-684.

Lamour, K.H., R. Stam, J. Pupe, and E. Huitema 2012. The oomycete broad-host-range pathogen Phytophthora capsici. Mol. Plant Pathol. 13:329-337.

Macías-Valdez, L., M.E. Baltazar-Brenes, E. González-Gaona, C. Serrano-Gómez, M.A. Galindo-Reyes, L.H. Maciel-Pérez, and
F.J. Robles-Escobedo. 2010. Nueva Tecnología de Manejo para el Control de la Marchitez del Chile en Aguascalientes. INIFAP, Num. 38, 56, p. 14. Aguascalientes, Mexico. May 2018. <https://pdfs.semanticscholar.org/57ed/ 0e3284c4ed564912926ec4e8f58a230ae12d.pdf? $\mathrm{ga}=2.258415811 .853265129 .1563488326$ 689055796.1563488326>

Michalska, A.M., S. Sobkowiak, B. Flis, and E. Zimmoch-Guzowska. 2016. Virulence and aggressiveness of Phytophthora infestans isolates collected in Poland from potato and tomato plants identified no strong specificity. Eur. J. Plant Pathol. 144:325-336.

Monroy-Barbosa, A. and P.W. Bosland. 2010. A rapid technique for multiple-race disease screening of Phytophthora foliar blight on single Capsicum annuum L. plants. HortScience 45: 1563-1566.

Monroy-Barbosa, A. and P.W. Bosland. 2011 Identification of novel physiological races of Phytophthora capsici causing foliar blight using the New Mexico recombinant inbred pepper lines set as a host differential. J. Amer. Soc. Hort. Sci. 136:205-210.

Oelke, L.M., P.W. Bosland, and R. Steiner. 2003. Differentiation of race specific resistance to Phytophthora root rot and foliar blight in Capsicum annuиm. J. Amer. Soc. Hort. Sci. 128:213-218

Palma-Martínez, E., V.H. Aguilar-Rincón, T. Corona-Torres, and O. Gómez-Rodríguez. 2017. Resistencia a Phytophthora capsici Leo en líneas de chile huacle (Capsicum annuum L.). Rev. Fitotec. Mex. 40:359-363.

Polach, F.J. and R.K. Webster. 1972. Identification of strains and inheritance of pathogenicity in Phytophthora capsici. Phytopathology 62:20-26.

Reyes-Tena, A., J.C. Huguet-tapia, K.H. Lamour, E.M. Goss, G. Rodríguez-Alvarado, G. Vázquez-Marrufo, R. Santillán-Mendoza, and S.P. Fernández-Pavía. 2019. Genome sequence data of six isolates of Phytophthora capsici from Mexico. Mol. Plant Microbe Interact. (In press.)

Ristaino, J.B. and S.A. Johnston. 1999. Ecologically based approaches to management of Phytophthora blight on bell pepper. Plant Dis. 83:1080-1089.

Saghai-Maroof, M.A., K.M. Soliman, R.A. Jorgensen, and R.W. Allard. 1984. Ribosomal DNA spacer-length polymorphisms in barley: mendelian inheritance, chromosomal location, and population dynamics. Proc. Natl. Acad. Sci. 81:8014-8018.

Silva-Rojas, H.V., S.P. Fernández-Pavía, C. Góngora-Canul, B.C. Macías-López, and G.D. Ávila-Quezada. 2009. Distribución espaciotemporal de la marchitez del chile (Capsicum annuит L.) en Chihuahua e identificación del agente causal Phytophthora capsici Leo. Rev. Mex. Fitopatol. 27:134-147.

Sy, O., R. Steiner, and P.W. Bosland. 2008. Recombinant inbred line differential identifies racespecific resistance to Phytophthora root rot in Capsicum annuum. Phytopathology 98:867-870.

Yin, J., K.L. Jackson, B.K. Candole, A.S. Csinos, D.B. Langston, and P. Ji. 2012. Aggressiveness and diversity of Phytophthora capsici on vegetable crops in Georgia. Ann. Appl. Biol. $160: 191-200$ 